\title{
噴霧火炎内すす生成の数値シミュレーション*
}

\author{
渡、邊 裕 章*1,*2, 黒 瀬 良 一*2 \\ 小森 悟*2, Heinz PITSCH*3
}

\section{A Numerical Simulation of Soot Formation in Spray Flames}

\begin{abstract}
Hiroaki WATANABE*4, Ryoichi KUROSE, Satoru KOMORI and Heinz PITSCH

${ }^{* 4}$ Energy Engineering Research Laboratory, Central Research Institute of Electric Power Industry (CRIEPI), 2-6-1 Nagasaka, Yokosuka-shi, Kanagawa, 240-0196 Japan

A two-dimensional numerical simulation is applied to spray flames formed in a laminar counterflow, and soot formation behavior is studied in terms of equivalence ratio and radiation in detail. N-decane $\left(C_{10} H_{22}\right)$ is used as a liquid spray fuel, and the droplet motion is calculated by the Lagrangian method. A one-step global reaction is employed for the combustion reaction model. A kinetically based soot model with flamelet model is employed to predict soot formation. Radiation is taken into account using the discrete ordinate method. The results show that the soot is formed in the spray diffusion flame region and its radiation emission increases with increasing the equivalence ratio of the droplet fuel. This trend is in good agreement with that of the luminous flame behavior observed in the experiment. The radiation is found to strongly affect the soot.formation behavior. Without the radiation model, the soot volume fraction is fatally overpredicted.
\end{abstract}

Key Words : Numerical Simulation, Spray Combustion, Soot, Thermal Radiation, Counterflow

\section{1. 緒言}

噴霧火炎中では, 液体燃料の微粒化, 油滴の気相へ の分散, 蒸発, 燃料蒸気の空気との混合反応といった 多くの過程が同時に進行しながら起こるため, その火 炎構造は極めて複雑であり，依然不明な点が多い，こ れまで著者らは, 層流対向流中に形成される噴霧火炎 の直接数值計算 (direct numerical simulation, DNS) を 実施し，油滴の群燃焼や火炎片の挙動について詳細な 検討を行ってきた ${ }^{(1)(2)(3)}$.中村 ${ }^{(2)}$ は, 噴霧火炎中に 形成される拡散火炎の挙動が, 実験 ${ }^{(4)}$ で観察されるす すの生成を示す輝炎の挙動と良く一致することを指摘 した. しかし，実際にすすの生成計算を行っていない ため，その詳細なメカニズムは議論していない.

近年, すすの生成量を予測するための手法として, 速度論に基づく生成モデルと火炎片 (flamelet) モデル を組み合わせた方法が提案されている. ここで flamelet モデルは，主要なガス成分に比べてかなり低濃度で算 出に多くの化学種と化学反応を要する, すすの前駆体

* 原稿受付 2006 年 9 月 29 日.

*1 正員, (財) 電力中央研究所エネルギー技術研究所 (乯 2400196 横須賀市長坂 2-6-1).

*2 正員, 京都大学大学院工学研究科(业606-8501 京都市左京 区吉田本町)

*3 Department of Mechanical Engineering, Stanford University (Stanford, CA 94305-3035)

E-mail : whiroaki@criepi.denken.or.jp
濃度を得るために用いられる.すすの前駆体としては, アセチレン $\left(\mathrm{C}_{2} \mathrm{H}_{2}\right)$ や芳香族炭化水素 $(\mathrm{PAH})$ 等が用い られる. Pitsch ら ${ }^{(5)}$ は，エチレンの噴流拡散火炎にお けるすすの生成を, PAH を前駆体とした核生成モデル により検討した. 一方, Wen $ら^{(6)}$ は，ケロシンの噴流 火炎を対象に，すす生成に及ぼす $C_{2} H_{2}$ や PAH を前駆 体とした核生成モデルの影響を調べた．これらの研究 は，ガス拡散火炎中のすす生成予測に対して flamelet モデルが有効であることを示している.

本研究では，層流対向流場に形成される噴霧火炎に 2 次元 DNS を実施することにより, 燃料油滴の当量 比と輻射の影響の観点から, 噴霧燃焼場におけるす すの生成挙動を明らかにすることを目的とした，すす の生成には， $\mathrm{C}_{2} \mathrm{H}_{2}$ を前駆体とした核生成，凝集，表 面成長，および酸化反応の各過程を考慮する。 また， 前駆体 $\left(\mathrm{C}_{2} \mathrm{H}_{2}\right)$ と酸化剂 $(\mathrm{OH}$ ラジカル) それぞれの濃 度は, flamelet モデルにより決定する. 輻射の効果は, discrete ordinate 法 $^{(7)}$ により考慮する。

\begin{tabular}{lllll} 
& & \multicolumn{1}{c}{ 記 } & & \multicolumn{2}{c}{ 号 } \\
& 速度 & $h$ & 比エンタルピ \\
$u_{i}$ & 压力 & $\lambda$ & 熱拡散率 \\
$\rho$ & 密度 & $Z$ & 混合分率 \\
$\sigma_{i j}$ & 応力テンソル & $\chi$ & スカラー消散率
\end{tabular}




$\begin{array}{llll}g_{i} & \text { 重力加速度 } & D_{k} & \text { 拡散係数 } \\ T & \text { ガス温度 } & c_{p} & \text { 混合ガスの比熱 } \\ L_{V} & \text { 油滴の蒸発潜熱 } & c_{p, d} & \text { 油滴の比熱 } \\ \tau_{d} & \text { 油滴の緩和時間 } & B_{M} & \text { 質量トランスファー数 } \\ A_{d} & \text { 油滴の投影面積 } & I & \text { 輻射強度 }\end{array}$

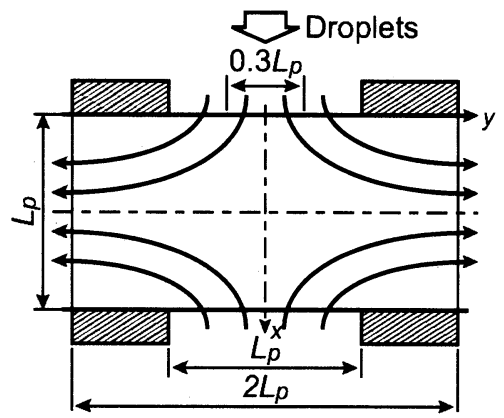

Fig. 1 Schematic drawing of computational setup.

\section{2. 計 算 方 法}

2.1 対象系 層流対向流場の噴霧火炎に対する 計算領域の設定は, 黄らの実験 ${ }^{(4)} に$ 従う (図 1). 計算 領域は，上下に位置するバーナポート径 $L_{p}$ によって 無次元化し, $x-y$ 座標の原点は上側ポート中心に置く. また, 液体燃料は n-デカン $\left(\mathrm{C}_{10} \mathrm{H}_{22}\right)$ とする. 上側ポー トからは, 常温常圧空気 $(300 \mathrm{~K}, 0.1013 \mathrm{MPa}$ ，および 酸素質量分率 $=0.2357$ ) が $-0.5 \leq y^{*} \leq 0.5$ より，ま た, $\mathrm{n}$-デカンの噴霧油滴が $-0.15 \leq y^{*} \leq 0.15$ より投 入される.下側ポートからは, 噴霧の安定的な着火の ため, 常温常圧空気と $\mathrm{n}$-デカン蒸気の予混合ガスが, $-0.5 \leq y^{*} \leq 0.5$ より投入される. 上下ポートから流入 する流体の速度は等しい.

本研究の燃焼反応には, 次の $\mathrm{n}$-デカンの一段総括反 応を用いる(8).

$$
\mathrm{C}_{10} \mathrm{H}_{22}+\frac{31}{2} \mathrm{O}_{2} \rightarrow 10 \mathrm{CO}_{2}+11 \mathrm{H}_{2} \mathrm{O}
$$

2.2 支配方程式本研究では, 速度論に基づく すす生成モデルを採用する. すすの前駆体に $\mathrm{C}_{2} \mathrm{H}_{2}$ を, 酸化剂には $O H$ ラジカルと酸素を考慮する．主要なガ ス組成は式 (1)により決定するが, 低濃度で算出に多 くの化学種と反応式を要する $\mathrm{C}_{2} \mathrm{H}_{2}$ と $\mathrm{OH}$ ラジカルの 濃度は, 後述する flamelet モデルにより決定する. た だし, flamelet モデルでは輻射強度輸送式を直接考慮 することができないため, 輻射項を含むエネルギー方 程式を解き，温度場を決定する．考慮する気相の支配 方程式は, 質量, 運動量, エネルギー，および混合分
率の保存式である.

$$
\begin{gathered}
\frac{\partial \rho}{\partial t}+\frac{\partial}{\partial x_{j}} \rho u_{j}=S_{m} \\
\frac{\partial \rho u_{i}}{\partial t}+\frac{\partial}{\partial x_{j}}\left(\rho u_{i} u_{j}+P \delta_{i j}-\sigma_{i j}\right)-\rho g_{i}=S_{u_{i}} \\
\frac{\partial \rho h}{\partial t}+\frac{\partial}{\partial x_{j}}\left[\rho u_{j} h-\rho \lambda \frac{\partial h}{\partial x_{j}}\right. \\
\left.\quad+\sum_{k=1}^{n} h_{k}\left(\rho \lambda-\rho D_{k}\right) \frac{\partial Y_{k}}{\partial x_{j}}\right]=S_{h} \\
\frac{\partial \rho Y_{k}}{\partial t}+\frac{\partial}{\partial x_{j}}\left(\rho u_{j} Y_{k}-\rho D_{k} \frac{\partial Y_{k}}{\partial x_{j}}\right)=S_{c o m b u, k}+S_{Y_{k}} \\
\frac{\partial \rho Z}{\partial t}+\frac{\partial}{\partial x_{j}}\left(\rho u_{j} Z-\rho D_{Z} \frac{\partial Z}{\partial x_{j}}\right)=S_{Z}
\end{gathered}
$$

ここで, $h_{k}, Y_{k}$ および $D_{k}$ はそれぞれ $k$ 番目の化学種 に対する比熱，質量分率および拡散係数である. $\delta_{i j}$ は クロネッカーのデルタ関数, $Z$ は flamelet モデルのた めに導入された混合分率である. $Z$ の拡散係数 $D_{Z}$ に は, 混合ガスの拡散係数を与える. $Y_{k} に は, 5 つ の$ 化 学種 $\left(\mathrm{O}_{2}, \mathrm{~N}_{2}, \mathrm{CO}_{2}, \mathrm{H}_{2} \mathrm{O}\right.$ および $\left.\mathrm{C}_{10} \mathrm{H}_{22}\right)$ を考慮する. $S_{m}, S_{u_{i}}, S_{h}, S_{Y_{k}}$ および $S_{Z}$ は, それぞれ油滴と気相の 相互作用（粒子運動，または蒸発）による質量, 運動 量, エンタルピ, 化学種, および混合分率の生成項を 表す．また， $S_{\text {combu }, k}$ は $\mathrm{n}$-デカン蒸気の燃焼に伴う生 成項である. $\rho$ は, 理想気体の状態方程式から導く.

燃料油滴の挙動は, ラグランジェ的に解くことによ り求める. 油滴密度は気相よりも十分に大きいと仮定 し, 油滴の挙動に対して, 抗力と重力の影響のみを考 慮し, 流れの剪断力に起因する揚力は無視する ${ }^{(9)}$. さ らに, 油滴の衝突, 分裂抢よび合体は考虑しない(10). 油滴の蒸発モデルには, 非平衡 Langmuir-Knudsen モ デルを用いる ${ }^{(11)}$. 油滴の位置 $\left(x_{d, i}\right)$, 速度 $\left(u_{d, i}\right)$, 温度 $\left(T_{d}\right)$, および質量 $\left(m_{d}\right)$ に関する保存式は, 次式で表さ れる.

$$
\begin{aligned}
& \frac{d x_{d, i}}{d t}=u_{d, i} \\
& \frac{d u_{d, i}}{d t}=\frac{f_{1}}{\tau_{d}}\left(u_{i}-u_{d, i}\right)+g_{i} \\
& \frac{d T_{d}}{d t}=\frac{\mathrm{Nu}}{3 \operatorname{Pr}}\left(\frac{c_{p}}{c_{p, d}}\right)\left(\frac{f_{2}}{\tau_{d}}\right)\left(T-T_{d}\right) \\
& +\frac{1}{m_{d}}\left(\frac{d m_{d}}{d t}\right) \frac{L_{V}}{c_{p, d}}+\frac{1}{m_{d} c_{p, d}}\left[A_{d} \varepsilon_{d}\left(\pi I-\sigma T_{d}^{4}\right)\right] \\
& \frac{d m_{d}}{d t}=-\frac{\mathrm{Sh}}{3 \operatorname{Sc}} \frac{m_{d}}{\tau_{d}} \ln \left(1+B_{M}\right)
\end{aligned}
$$

ここで, $f_{1}$ と $f_{2}$ はそれぞれ油滴の蒸発による抗力と熱 伝達に関する修正係数 ${ }^{(12)}$ ，。はステファン・ボルッマ 
ン定数 $\left(5.67 \times 10^{-8} \mathrm{~W} /\left(\mathrm{m}^{2} \mathrm{~K}^{4}\right)\right)$ である. $\varepsilon_{d}$ の粒子放射 係数には，炭化水素油滴の放射率 $(=0.4)^{(13)}$ を与える.

以上の支配方程式わよび計算手法の詳細については, 文献 ${ }^{(2)(3)}$ を参照されたい。

2.3 すす生成モデル 本研究では，すすの挙動 を，次に示すすすの数密度 $(N)$ と質量密度 $(M)$ の各保 存式を解くことによって求める.

$$
\frac{\partial \rho \phi}{\partial t}+\frac{\partial}{\partial x_{j}}\left(\rho u_{j} \phi-\rho D_{s} \frac{\partial \phi}{\partial x_{j}}\right)=S_{\phi}
$$

ここで， $D_{s}$ は拡散係数， $\phi$ は $N$ または $M$ を表す，た だし， $N$ と $M$ は次式で与えられる。

$$
N=N_{A} \rho \phi_{N}, \quad M=\rho \phi_{M}
$$

ここで， $N_{A}$ はアボガドロ数 $\left(6.02 \times 10^{26} \mathrm{kmol}^{-1}\right)$ であ る. また，それぞれの保存式の生成項は，次式で表す ことができる

$$
\begin{aligned}
& S_{N}=\frac{1}{N_{A}}\left[\left(\frac{d N}{d t}\right)_{\text {Inc. }}+\left(\frac{d N}{d t}\right)_{\text {Coa. }}\right] \\
& S_{M}= \\
& \quad \frac{M_{P}}{N_{A}}\left(\frac{d N}{d t}\right)_{\text {Inc. }}+\left(\frac{d M}{d t}\right)_{\text {Gro. }}+\left(\frac{d M}{d t}\right)_{\text {Oxi. }}
\end{aligned}
$$

ここで, $M_{P}$ はすすのモル質量 $(1,200 \mathrm{~kg} / \mathrm{kmol})$ である (14). 本研究では，すすの生成は，核生成 (inception), 凝集 (coagulation), 表面成長 (growth) および酸化反応 (oxidation) の各過程から構成されるものと仮定する.

すすの前駆体として $C_{2} H_{2}$ を仮定し，すすの核生成 速度には, 次式で表される Leung $ら^{(14)}$ の単純化モデ ルを用いる。

$$
\left(\frac{d N}{d t}\right)_{\text {Inc. }}=c_{1} N_{A}\left(\rho \frac{Y_{C_{2} \mathrm{H}_{2}}}{W_{C_{2} \mathrm{H}_{2}}}\right) e^{-\frac{21100}{T}}
$$

ここで, $c_{1}=54 s^{-1}$ である ${ }^{(15)}$.

すすの凝集は, すす粒子同士の衝突頻度に比例する と考えられる. 衝突頻度は, すすの粒径と䨌囲気ガス の平均自由行程から決めることができ，凝集速度は次 式で与えられる ${ }^{(16)}$.

$$
\begin{aligned}
& \left(\frac{d N}{d t}\right)_{\text {Coa. }}= \\
& -\left(\frac{24 R}{\rho_{\text {soot }} N_{A}}\right)^{1 / 2}\left(\frac{6}{\pi \rho_{\text {soot }}}\right)^{1 / 6} T^{1 / 2} M^{1 / 6} N^{11 / 6}
\end{aligned}
$$

ここで, $R$ は一般ガス定数， $\rho_{\text {soot }}$ はすすの密度 $\left(2,000 \mathrm{~kg} / \mathrm{m}^{3}\right)$ である.

すすの表面成長は，核生成と同様に， $\mathrm{C}_{2} \mathrm{H}_{2}$ が寄与す るものと仮定する ${ }^{(17)(18)}$ ，このとき，表面成長速度は，

$$
\left(\frac{d M}{d t}\right)_{\text {Gro. }}=
$$

$$
c_{4}\left(\rho \frac{Y_{C_{2} H_{2}}}{W_{C_{2} H_{2}}}\right) e^{-\frac{12100}{T}}\left[(\pi N)^{1 / 3}\left(\frac{6 M}{\rho_{\text {soot }}}\right)^{2 / 3}\right]
$$

ここで, $c_{4}=9000.6 \mathrm{~kg} \cdot \mathrm{m} /(\mathrm{kmol} \cdot \mathrm{s})$ である.

$\mathrm{OH}$ ラジカルと酸素をすすの酸化反応の酸化刘とし て考慮する ${ }^{(19)(20)}$ ：このとき，すすの酸化反応速度は， $O H$ ラジカルによる反応速度と酸素による反応速度と の加算の形で表される ${ }^{(6)}$.

$$
\begin{aligned}
& \left(\frac{d M}{d t}\right)_{O x i .}=-c_{5} \eta \rho \frac{Y_{O H}}{W_{O H}} T^{1 / 2}(\pi N)^{1 / 3}\left(\frac{6 M}{\rho_{\text {soot }}}\right)^{2 / 3} \\
& -c_{6} \rho \frac{Y_{O_{2}}}{W_{O_{2}}} e^{-\frac{19778}{T}} T^{1 / 2}(\pi N)^{1 / 3}\left(\frac{6 M}{\rho_{\text {soot }}}\right)^{2 / 3}
\end{aligned}
$$

ここで, $\eta=0.13, c_{5}=105.81 \mathrm{~kg} \cdot \mathrm{m} /\left(\mathrm{kmol} \cdot \mathrm{K}^{1 / 2} \cdot \mathrm{s}\right)$, および $c_{6}=8903.51 \mathrm{~kg} \cdot \mathrm{m} /\left(\mathrm{kmol} \cdot \mathrm{K}^{1 / 2} \cdot \mathrm{s}\right)$ である.

$T$ と $O_{2}$ の濃度は, 式 (1), (4) および (5) から決定 し, $\mathrm{C}_{2} \mathrm{H}_{2}$ と $\mathrm{OH}$ ラジカルの濃度は, steady flamelet モ デルにより決定する. Steady flamelet モデルでは, 物 理空間の各位置における $\mathrm{C}_{2} \mathrm{H}_{2}$ と $\mathrm{OH}$ ラジカルの濃度 を, flamelet ライブラリと呼ばれるデータベースを用 いて決める. Flamelet ライブラリは， $Z$ 空間において, 1 次元火炎片方程式を解くことで得られる. 本研究で は, $Z$ 空間における n-デカン / 空気の 1 次元層流対向 流拡散火炎方程式を, CFX-RIF ${ }^{(21)}$ を用いて計算した. この計算には, 112 の化学種と 883 の素反応過程を考 慮した. 物理空間と $Z$ 空間をやりとりするパラメータ には, $Z$ と次式で定義される $\chi$ を用いる.

$$
\chi=2 D_{Z}|\nabla Z|^{2}
$$

なお，本研究では，式 (6) の $Z$ 保存式を解く際に, 下側ポートから流入する予混合ガスに由来する $Z$ の輸 送は無視した。

2.4 輻射モデル 本研究では, 輻射計算に discrete ordinate 法(7)を採用する，ある方向 $\Omega$ に対す る輻射強度 $I$ の輸送式は，次式で表される.

$$
\Omega \cdot \nabla I(r, \Omega)=-(\alpha+\kappa) I(r, \Omega)+\alpha I_{b}(r)
$$

ここで， $I_{b}$ は各位置における黒体輻躬強度， $\alpha$ と $\kappa$ は それぞれ， $\mathrm{CO}_{2}, \mathrm{H}_{2} \mathrm{O}, \mathrm{C}_{10} \mathrm{H}_{22}$ およびすすの濃度から 決まるガス吸収係数 ${ }^{(22)}$ と粒子数密度から決まる散乱係 数 ${ }^{(23)}$ である. 各セルからの輻射強度の輸送方向は, $S_{8}$ 近似によって決める. 式(4)のエネルギー保存式にお ける輻射による生成項は, 次式で与えられる.

$$
-\dot{Q}_{r a d}=\alpha\left(\int_{4 \pi} I d \Omega-\sigma T^{4}\right)
$$




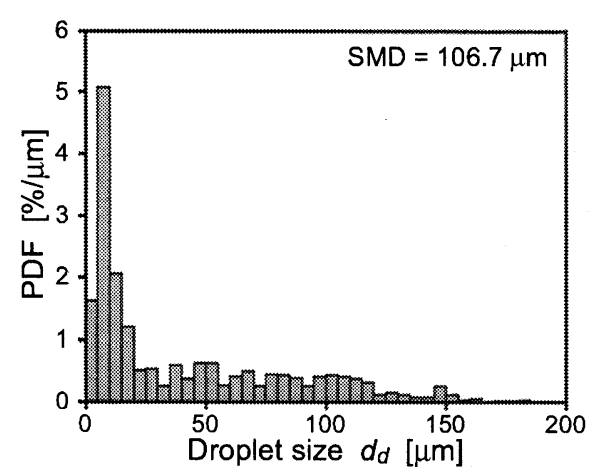

Fig. 2 Droplet size distribution.

2.5 計算条件 縦 $20 \mathrm{~mm} \times$ 横 $40 \mathrm{~mm}$ の計算領 域を $200 \times 400$ の等間隔格子 (コントロールボリュー ムの実寸法 $100 \mu \mathrm{m} \times 100 \mu \mathrm{m})$ に分割した. 支配方程 式の解法には，有限体積法に基づく SIMPLE 法を採用 した. 空間差分には 4 次精度中心差分を，時間差分に は完全陰解法を用いた，また，油滴に関する時間差分 は, 2 次精度 Adams-Bashforth 法を用いて解いた。

本研究における計算では, 伸張率 $(a)$ を $40 \mathrm{~s}^{-1}$, お よび噴霧の平均粒径 $(S M D)$ を $106.7 \mu \mathrm{m}$ とした．ただ し, $a$ は入口ガス流速 $\left(u_{0}\right)$ と上下ポート間距離 $\left(L_{p}\right)$ で 定義した $\left(a \equiv 2 u_{0} / L_{p}\right)$. また，噴霧の粒径分布は，対 応する PDA(Phase Doppler Anemometry) 計測により 得た (図 (2)). 噴霧の供給当量比 $\left(\phi_{l}\right)$ の影響を調べる ため， $\phi_{l}$ を $1.26 ， 0.84$ ，および 0.63(それぞれ， RE1， RE2, およびRE3) と変化させた. これらの条件に対し ては，輻射を考慮した．ただし， $\phi_{l}$ は，上側ポートの $-0.15 \leq y^{*} \leq 0.15$ から供給される空気量と噴霧供給量 によって定義した. 加えて, 輻射の影響を調べるため, $\phi_{l}=1.26$ に対して，輻射を考慮しない条件 (E1)を計 算した．本研究で検討する条件を表 1 にまとめる. 油 滴の初期位置は一様乱数を用いて決定し, その速度は 気相の流入速度に等しいとした。 ポート径 $L_{p}(=0.02$ $\mathrm{m})$ と入口流速 $u_{0}(=0.4 \mathrm{~m} / \mathrm{s})$, および常温空気性状か ら求まるレイノルズ数は 500 である. 下側ポートから の予混合ガス火炎に対して, 上側ポートから燃料油滴 を投入した後, $550 \mathrm{~ms}(0.1 \mathrm{~ms} \times 5,500$ タイムステップ 後まで計算を行い, 最後の 500 ステップ分を用いて統 計量を算出した.
Table 1 Cases presented.

\begin{tabular}{c|c|c}
\hline Cases & Equivalence ratio, $\phi_{l},[-]$ & Radiation \\
\hline RE1 & 1.26 & Yes \\
RE2 & 0.84 & Yes \\
RE3 & 0.63 & Yes \\
E1 & 1.26 & No \\
\hline
\end{tabular}
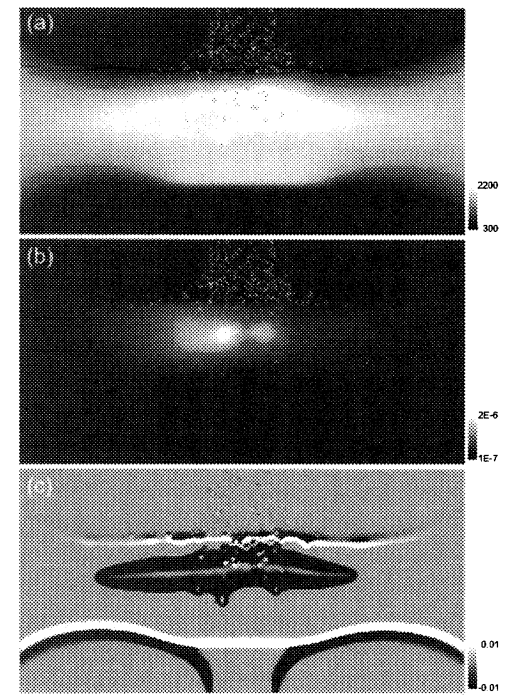

Fig. 3 Instantaneous distributions of (a)gaseous temperature, (b)soot volume fraction, and (c)flame index, for case RE1.

\section{3. 結果および考察}

3.1 すす生成の一般的特性 図 3(a) (c) に, RE1(噴霧の供給当量比 $\phi_{l}=1.26$, 伸張率 $a=40 \mathrm{~s}^{-1}$, および噴霧粒径 $S M D=106.7 \mu \mathrm{m}$ ) における, (a) ガ ス温度 $(T)$, (b) すすの体積分率 $\left(V_{S}\right)$, および (c)flame index $(F I)$ の瞬間分布をそれぞれ示す，ただし，図中の 白い点は, 各油滴粒子の位置を表す.また, FI は予混 合火炎と拡散火炎を判別するパラメータであり，次式 で定義される(24).

$$
F I=\nabla Y_{C_{10} H_{22}} \cdot \nabla Y_{O_{2}}
$$

$F I$ は，正であれば予混合火炎を，負であれば拡散火 炎を表す。上側ポートから投入された油滴の数が，図 3(a) 中央付近に見られる高温の領域において急速に減 少することから, 油滴は主にこの領域で蒸発し, 燃焼 していることがわかる，また， $V_{s}$ は，この高温域の上 流側 $\left(x / L_{p}\right.$ が小さくなる方向) 部分において高い值を 示し，その領域は，中央付近に大きく拡がる拡散火炎 の位置と一致する (図 3(b),(c)). このことから，すす は拡散火炎中に生成されることが確認できる. なお, 
このような拡散火炎の発達は, 油滴の群燃焼に起因す ることが著者らによって確認されている(2).

図4(a)〜(c)に, RE1における, (a) ガス温度 $(\bar{T})$, 混 合分率 $(\bar{Z})$, すす体積分率 $\left(\bar{V}_{s}\right)$, および油滴蒸発速度 $\left(\bar{S}_{m}\right)$, (b) すすの前駆体と酸化剂の質量分率 $\left(\bar{Y}_{k}\right)$, お よび, (c) すすの質量密度方程式の生成項 $\left(\bar{S}_{M}\right)$ の中心 軸上の時間平均值分布をそれぞれ示す. 図 4(a) から, $x / L_{p}=0.3$ 付近において, 燃料蒸気は着火し, $\bar{T}$ が急 速に上昇することがわかる． $\bar{T}$ の上昇とともに， $\bar{S}_{M}$ は 上昇し, $x / L_{p}=0.35$ 付近でピーク值をもつ.これに 対して, 油滴の蒸発により生成される $\bar{Z}$ とすすの体積 分率 $\left(\bar{V}_{S}\right)$ は, $\bar{S}_{M}$ よりも下流側のほぼ同じ位置にピー ク值をもち，その分布形状も良く似た傾向を示してい る. 図4(b)において, すすの前駆体であるアセチレン $\left(\mathrm{C}_{2} \mathrm{H}_{2}\right)$ の質量分率 $\left(\bar{Y}_{\mathrm{C}_{2} \mathrm{H}_{2}}\right)$ は, すすの酸化剂である $\mathrm{OH}$ ラジカルと酸素の質量分率 $\left(\right.$ bar $Y_{\mathrm{OH}}$ および bar $\left.\mathrm{O}_{\mathrm{O}_{2}}\right)$ が それぞれその最低值とゼロ值をとる $x / L_{p}=0.4$ 付近 でピーク值をもつ.これらに起因するすす生成速度の 挙動が, 図4(c) において見られる.すすすのトータルの 生成速度は, 酸化速度がピーク值をもつ $x / L_{p}=0.3 \sim$ 0.4 を除き，ほとんどが核生成速度に一致しており，表 面成長の影響はほとんど見られない，すすの酸化速度 は, そのピーク值を $\bar{Y}_{\mathrm{C}_{2} \mathrm{H}_{2}}$ のピーク值の上流側で $\bar{Y}_{\mathrm{OH}}$ のピーク值付近にもち, $\bar{Y}_{O H}$ の急激な減少とともにゼ 口に向かう. 一方, 下流側の酸化速度は, ほぼゼロで ある.これは, 油滴の群燃焼により既に酸素が消費さ れていることに起因する.

3.2 噴霧の供給当量比の影響噴霧の供給当量 比 $\left(\phi_{l}\right)$ の影響を調べるため, $\phi_{l}=1.26,0.84$ および 0.63 の 3 条件 (それぞれ，RE1，RE2，およびRE3)に ついて検討する. 図 5(a) (d) は, RE1〜RE3 におけ る, (a) ガス温度 $(T)$, (b)flame index $(F I)$, および, (c) すすからの輻射エネルギー $\left(E_{s}\right)$ の瞬間分布と, (d) 対 応する実験において観察される輝炎の写真 ${ }^{(4)}$ の比較で ある，ただし， $E_{s}$ は，すす体積分率 $\left(V_{s}\right)$ とガス温度 (T) から次式で定義する.

$$
E_{s}=V_{s} \sigma T^{4}
$$

写真に現れる輝炎の明るさは, すすの燃焼に伴う輻射 エネルギーの放出に比例すると考えられるため, $E_{s}$ の 分布は，輝炎の写真と比較することが可能である．図 5(a) から， $\phi_{l}$ が増加すると, 図の中央部に現れる高温 の領域が拡大することがわかる．これは，噴霧燃燒に よる拡散火炎が発達することに対応している(図 5(b)). また，図5(c)より，すすからの輻射エネルギー $\left(E_{s}\right)$ は, $\phi_{1}$ の増加に従って，増加することがわかる．この傾向 は，図 5(b) に見た拡散火炎領域の拡大と対応してお

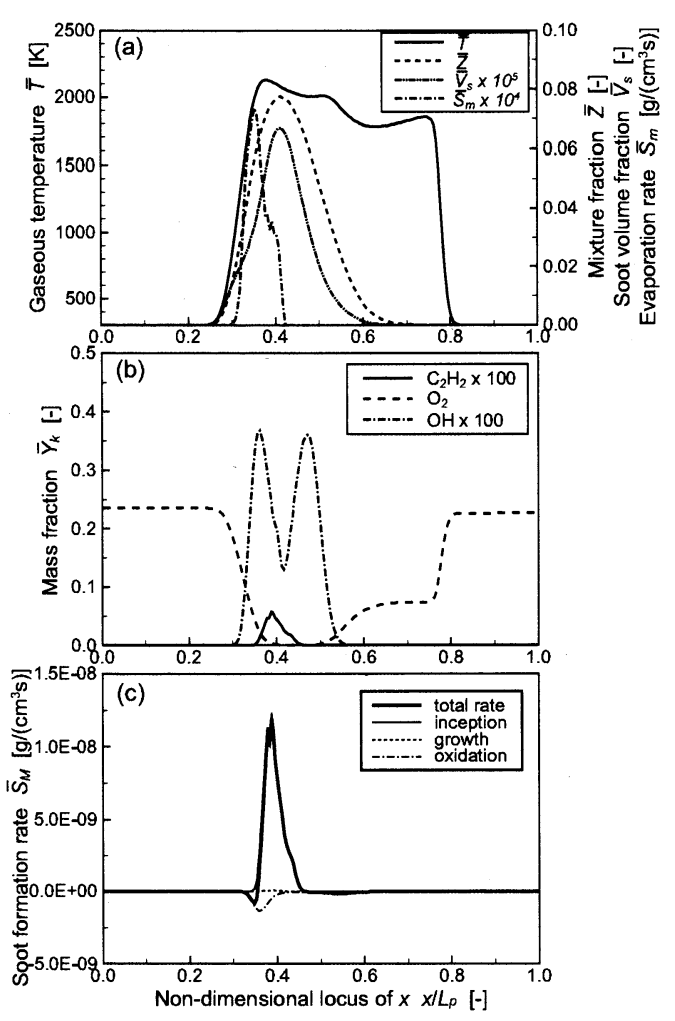

Fig. 4 Time-mean profiles of (a)gaseous temperature, mixture fraction, soot volume fraction and evaporation rate of droplets, (b)mass fractions of soot precursor and oxidizers, and (c)source terms of soot mass density, for case RE1.

り，実験において観察される輝炎の傾向とも定性的に 一致する (図 5(d)). 実際, 実験において, 輝炎の発生 が, RE1では定常的に見られるのに対して, RE3では 間欠的であるなど， $\phi_{l}$ に対して敏感な様子が観察され ている.

図 6(a), (b) に，RE1〜RE3 における, (a) ガス温度 $(\bar{T})$, および油滴蒸発速度 $\left(\bar{S}_{m}\right)$, (b) すす体積分率 $\left(\bar{V}_{s}\right)$, および $\mathrm{C}_{2} \mathrm{H}_{2}$ の質量分率 $\left(\bar{Y}_{\mathrm{C}_{2} \mathrm{H}_{2}}\right)$ の中心軸上の時間平 均值分布をそれぞれ示す. 図6(a) から, RE1〜RE3に おいて，それぞれの $\bar{T}$ のピーク值の差は，100 K 以内 にあり，それほど大きな違いは見られないことがわか る. しかしながら， $\bar{V}_{s}$ は， $\phi_{l}$ の増加に従い, 劇的に増 加する(図6(b)). これは， $\bar{Y}_{C_{2} H_{2}}$ の増加，すなわち，す すの前駆体の生成が $\bar{S}_{m}$ の増加と共に顕著になるため である. 

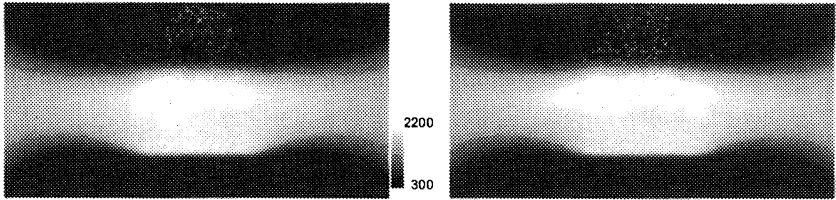

(a) Gaseous temperature
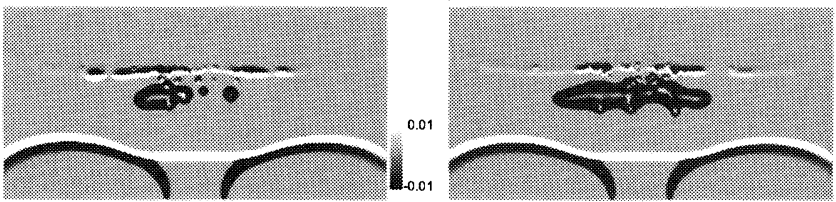

(b) Flame index
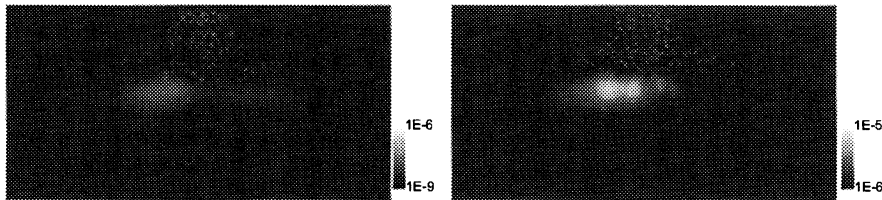

(c) Soot radiation emission

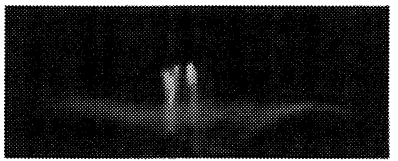

$\phi_{1}=0.63$

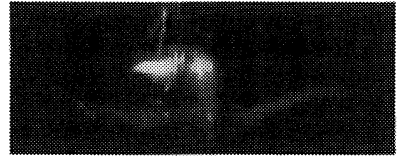

(d) Experiment
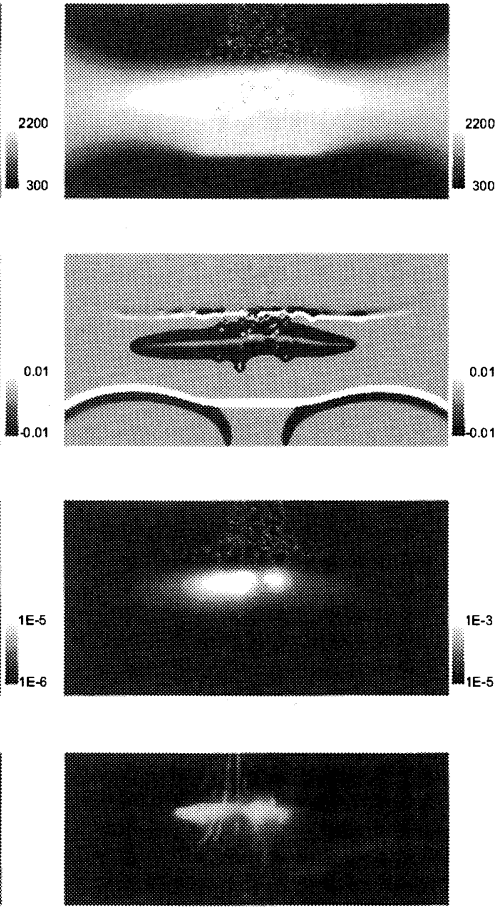

$\phi_{1}=1.26$

Fig. 5 Instantaneous distributions of (a)gaseous temperature, (b)flame index, (c)soot radiation emission, and (d)experiment's photographs, for $\phi_{l}=1.26,0.84$ and 0.63 (case RE1, RE2 and RE3, respectively).

\section{3 輻射の影響生成挙動に及ぼす輻} 射の影響を調べるため, 輻射を考慮しない条件 (E1, $\left.\phi_{l}=1.26\right)$ を計算し，輻射を考慮した条件 (RE1) と比 較する. 図7(a)〜 (c)に, E1 における, (a) ガス温度 $(T)$, (b) すすの体積分率 $\left(V_{s}\right)$, および (c)flame index $(F I)$ の 瞬間分布をそれぞれ示す. RE1(図 3(a)) と比較すると, E1 における $T$ の分布 (図 7(a)) では，中央部に現れる 高温の領域が大きく拡がっていることがわかる. また, 図 3(b) と図 7(b) の $V_{s}$ の分布を比較すると，すすの生 成量は, E1 の方が RE1 よりも多いことがわかる.さ らに，E1における火炎構造を見てみると，拡散火炎 領域が，RE1におけるそれよりもわずかに上下方向に 拡大している様子が観察できる (図 3(c), 図 7(c)).

定量的な比較を行うため，図 8(a)，(b)に，RE1 と E1 における，(a) ガス温度 $(\bar{T})$, および油滴蒸発速度 $\left(\bar{S}_{m}\right)$, (b) すす体積分率 $\left(\bar{V}_{s}\right)$, および $C_{2} H_{2}$ の質量分率 $\left(\bar{Y}_{C_{2} H_{2}}\right)$ の中心軸上の時間平均值分布の比較をそれぞれ 示す．図 8(a) から，輻射を考虑しないE1 では，輻射 を考慮した RE1 よりも， $\bar{T}$ のピーク值が $300 \mathrm{~K}$ 程度高 くなり，燃料油滴の着火はより上流側で起こることが

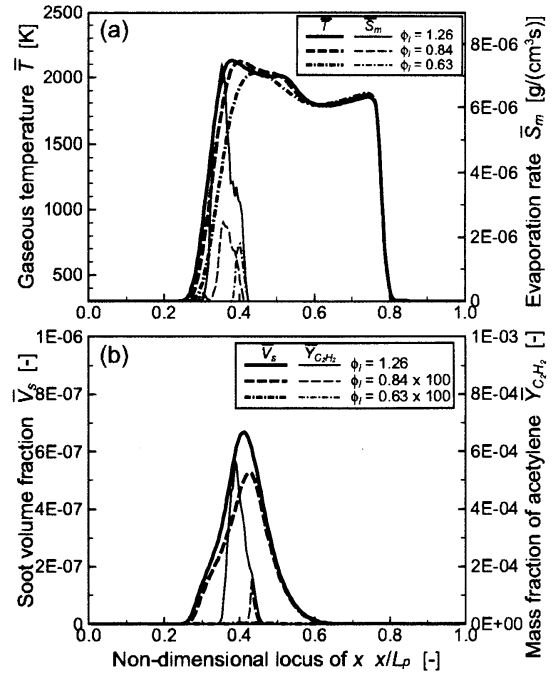

Fig. 6 Comparison of time-mean profiles of (a)gaseous temperature and evaporation rate of droplets, (b)soot volume fraction and mass fraction of $\mathrm{C}_{2} \mathrm{H}_{2}$, for $\phi_{l}=1.26,0.84$ and 0.63 (case RE1, RE2 and RE3, respectively). 


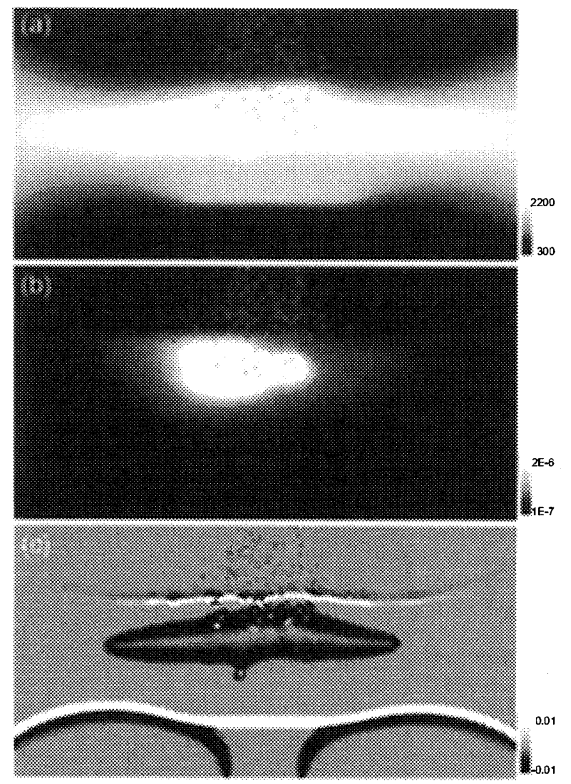

Fig. 7 Instantaneous distributions of (a)gaseous temperature, (b)soot volume fraction, and (c)flame index, for case E1.
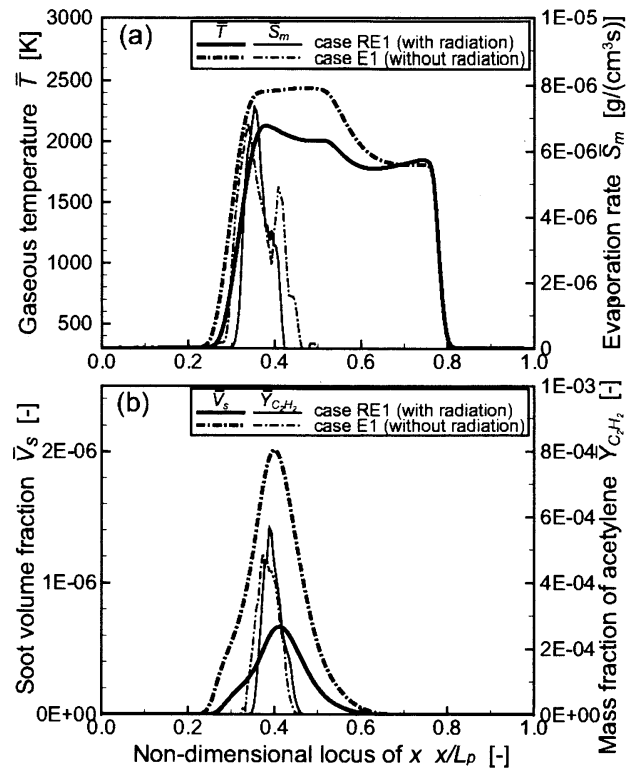

Fig. 8 Comparison of time-mean profiles of (a)gaseous temperature and evaporation rate of droplets, (b)soot volume fraction and mass fraction of $\mathrm{C}_{2} \mathrm{H}_{2}$, between the cases of with and without radiation (case RE1 and $\mathrm{E} 1$, respectively).
わかる. また，これに伴い，E1 では RE1 よりも， $\bar{S}_{m}$ の上昇が上流側で起こる.さらに, E1 における $\bar{V}_{s}$ は, RE1 のそれよりも大幅に高い值を示す(図 8(b)). これ らの原因としては, E1 において, 未燃ガスや燃料油 滴の温度が火炎温度よりも大幅に低いことに起因する 輻射熱損失が考慮されていないことが考えられる. 式 (15) (18)に従うと, 一見, すすの酸化は, その速度 が核生成や表面成長の速度と同様に, 温度が上昇する に従って大きくなるため，すすの生成を抑制するよう に見える. しかし, 拡散火炎内では, 油滴の群燃焼に より酸化剤となる酸素が既に消費されているため, す すの酸化反応は進まない，その結果，輻射を考慮しな い場合のすすの生成が促進されるものと考えられる.

\section{4. 結 論}

本研究では, 層流の 2 次元対向流場に形成される nデカンの噴霧火炎に対して DNS を実施することによ り, すすの生成挙動について検討を行った. 得られた 主な知見は，以下の通りであった。

1. すすは，主に拡散火炎領域において形成される。 また, すすの燃焼に伴う輻射のエネルギーは, 供 給当量比の増加に伴ってすすの前駆体濃度が増加 するため, 劇的に大きくなる. この傾向は, 実験 において観察される輝炎の挙動と定性的に良く一 致する.

2. 輻射を考慮した場合に比較して, 考虑しない場合 におけるすすの生成量は大幅に増加する.これは, 低温の未燃ガスや液滴からの輻射熱損失がないこ とによる火炎温度の上昇により，すすの核生成や 表面成長が促進されるためである.この結果は, すすの生成量を正確に予測するためには，輻射を 考慮することが不可欠であることを示している.

\section{謝 辞}

本研究を遂行するにあたり, 大阪大学赤松史光助教 授に実験データの提供と貴重な助言を頂いた。また， 電力中央研究所 馬場雄也氏, 黄承敏氏, 大高円氏, 大 阪大学 中村摩理子氏, および株式会社フルーエント・ アジアパシフィック 福地健氏には, コード開発におい てご協力頂いた. さらに, スタンフォード大学 Matthias Ihme 氏，および Olivier Desjardins 氏には，貴重な助 言を頂いた. 本研究の一部は文部科学省科学研究費補 助金 (課題番号 17560186) およびゼネラル石油研究奖 励財団の援助を受けて行われた. ここに記して, 謝意 
を表する.

\section{文献}

(1) Kurose, R., Desjardins, O., Nakamura, M., Akamatsu, F. and Pitsch, H., Numerical simulation of spray flames, CTR Annual Research Briefs-2004, Center for Turbulence Research, NASA Ames/Stanford Univ. (2004), 269-280.

(2) Nakamura, M., Akamatsu, F., Kurose, R. and Katsuki, M., Combustion mechanism of liquid fuel spray entering gaseous flame front, Phys. Fluids, 17 (2005), 123301.

(3) Watanabe, H., Kurose, R., Hwang, S.-M. and Akamatsu, F., Characteristics of flamelet in spray flames formed in a laminar counterflow, Combust. Flame, 148 (2007), 234248.

(4) Hwang, S.-M., Saito, H., Takada, S., Akamatsu, F. and Katsuki, M., Observation of spray flame stabilized in a laminar counterflow field, Proc. thirty-eighth Japanese Combust. Symp. (2000), 201-202.

(5) Pitsch, H., Riesmeier, E. and Peters, N., Unsteady flamelet modeling of soot formation in turbulent diffusion flames, Combust. Sci. and Tech., 158 (2000), 389-406.

(6) Wen, Z., Yun, S., Thomson, M. J. and Lightstone, M. F., Modeling soot formation in turbulent kerosene/air jet diffusion flame, Combust. Flame, 135 (2003), 323-340.

(7) Fiveland, W. A., Three-dimensional radiative heattransfer solutions by the discrete-ordinates method, $J$. Thermophysics, 2 (1988), 309-316.

(8) Westbrook, C. K. and Dryer, F. L., Chemical kinetic modeling of hydrocarbon combustion, Prog. Energy, Combust. Sci., 10 (1984), 1-57.

(9) Kurose, R. and Komori, S., Drag and lift forces on a rotating sphere in a linear shear flow, J. Fluid Mech., 384 (1999), 183-206.

(10) Ham, F., Apte, S. V., Iaccarino, G., Wu, X., Herrmann, M., Constantinescu, G., Mahesh, K. and Moin, P., Unstructured LES of reacting multiphase flows in realistic gas turbine combustors, CTR Annual Research Brief-2003, Center for Turbulence Research, NASA Ames/Stanford Univ. (2003), 139-159.

(11) Miller, R. S. and Bellan, J., Direct numerical simulation of a confined three-dimensional gas mixing layer with one evaporating hydrocarbon-droplet-laden stream, J. Fluid Mech., 384 (1999), 293-338.

(12) Kurose, R., Makino, H., Komori, S., Nakamura, M., Akamatsu, F. and Katsuki, M., Effects of outflow from the surface of a sphere on drag, shear lift, and scalar diffusion, Phys. Fluids, 15 (2003), 2338-2351.

(13) Tseng, C. C. and Viskanta, R., Effect of radiation absorption on fuel droplet evaporation, Combust. Sci. and Tech., 177 (2005), 1511-1542.

(14) Leung, K. M., Lindstedt, R. P. and Jones, W. P., Simplified reaction mechanism for soot formation in nonpremixed flames, Combust. Flame, 87 (1991), 289-305.

(15) Brookes, S. J. and Moss, J. B., Predictions of soot and thermal radiation properties in confined turbulent jet diffusion flames, Combust. Flame, 116 (1999), 486-503.
(16) Puri, R., Richardson, T. F., Santoro, R. J. and Dobbins, R. A., Aerosol dynamic processes of soot aggregates in a laminar ethene diffusion flame, Combust. Flame, 92 (1993), 320-333.

(17) Frenklach, M., Clary, D. W., Gardiner, J. and Stein, S. E., Detailed kinetic modeling of soot formation in shochtube pyrolysis of acetylene, Proc. Twentieth Symp. (Int.) on Combust., The Combustion Institute, (1984), 887-901.

(18) Harris, S. J., Weiner, A. M. and Blint, R. J., Formation of small aromatic molecules in a sooting ethylene flame, Combust. Flame, 72 (1988), 91-109.

(19) Neoh, K. G., Howard, J. B. and Sarofim, A. F., Particulate carbon formation during combustion, Plenum, (1981), 261.

(20) Lee, K. B., Thring, M. W. and Beer, J. M., On the rate of combustion of soot in a laminar soot flame, Combust. Flame, 6 (1962), 137-145.

(21) CFX-RIF Manual, Ansys, Inc. (2005).

(22) Grosshandler, W. L., A narrow-band model for radiation calculation in a combustion environment, NIST Technical Note, 1402 (1993).

(23) Modest, M. F., Radiative heat transfer, McGraw-Hill, Inc., (1993).

(24) Yamashita, H., Shimada, M. and Takeno, T., A numerical study on flame stability at transition point of jet diffusion flames, Proc. Twenty-fifth Symp. (Int.) on Combust., The Combustion Institute, (1996), 27-34. 